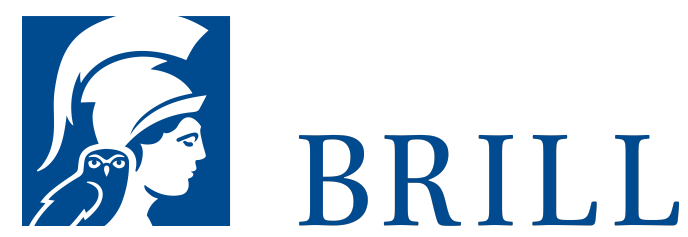

\title{
Some Oxford papyri (P.Oxford)
}

Text and plates

Author: Wegener

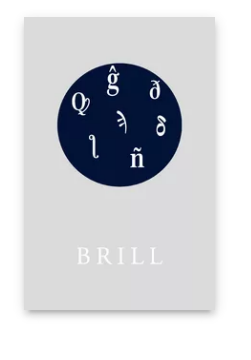

Language:

English

Subjects:

General,

Classical Studies

Publisher: Brill

\section{Series:}

Papyrologica

Lugduno-

Batava, Volume:

3

E-Book (PDF)

Released online:

O2 Mar 2020

ISBN: $978-90-$

04-42993-2

List price

USD $\$ 42.00$

Hardback

Publication date:

o1 Jun 1942

ISBN: $978-90-$

04-42878-2 
For more information see brill.com

Order information: Order online at brill.com +44330 333 0049 | customerservices@brill.com Submission information: brill.com/authors

Titles published by Brill | Fink, Brill | mentis or Brill | Schöningh: +49(o)715413279216| brill@brocom.de 